\title{
Development of Problem-Based Learning Models in Improving Creative Thinking Skills for Students of PGSD FIP Unimed
}

\author{
$1^{\text {st }}$ Sorta Simanjuntak ${ }^{1}, 2^{\text {nd }}$ Laurensia Masri Peranginangin 2 , $3^{\text {rd }}$ Demmu Karo Karo ${ }^{3}$ \\ \{Sortasimanjuntak10@gmail.ac.id ${ }^{1}$ \} \\ Elementary School Teacher Education Study Program, Faculty of Education, Universitas Negeri \\ Medan, Indonesia ${ }^{1,2,3}$
}

\begin{abstract}
This study aims to determine the development process and determine the validity (feasibility) of the Problem Based Learning Model in Improving Creative Thinking Ability of PGSD FIP Unimed Students. This research method is Research \& Development with a model ADDIE (Analysis, Design, Development, Implementation and Evaluation).Data collection techniques were obtained from questionnaires. Data analysis uses quantitative data. The results of the study stated thatThe design validation phase I obtained a score of 138 with a feasibility percentage obtained of $78 \%$, with the criteria "Eligible with revision". After revision, the results of the second validation got a score of 178 with the percentage of feasibility getting results of $89 \%$. The percentage value obtained in the second validation is included in the "Very Eligible" criteria. Material Feasibility Validation obtained a score of 147 out of a maximum score of 200 with an average result of $74 \%$, then the second validation result obtained a score of 184 with the percentage of eligibility obtained was $92 \%$ with very qualified criteria. Learning at the Elementary School Teacher Education Study Program, FIP Medan State University.
\end{abstract}

Keywords: Problem-based learning model, design and material feasibility.

\section{Introduction}

Teaching and learning activities are a process of interaction between students and educators and with learning resources in a learning environment, as in the formulation of UUSPN N0 20 of 2003. This interaction will be more effective if learning is conditioned and managed in an integrated manner. towards achieving the expected goals. As Corey's formulation in Sagala 2003 [1] reads: learning is a process in which a student environment that is provided intentionally must be managed and regulated in order to allow behavior change for students. The learning process must be organized and carried out interactively including inspiring, fun for students, challenging, motivating students to participate actively and providing sufficient space for initiative,

From the other side, Rusman 2012 [2] said: Education must foster critical individual development and high thinking skills in order to be able to take part in evil. Educational outcomes include the competencies and intelligence needed to take part in the 21st century. Therefore, all student learning activities are manifested in the form of behavior: creative, critical thinking, capable, reflective, and active learning in various situations and conditions. 
Because of that Sudarwan 2000 [3] said that the success of teachers in carrying out their professional duties can be seen from their ability to condition challenging learning processes and foster students' abilities to: solve problems encountered, think critically and creatively, work collaboratively and independently in various challenging activities. Learning is conditioned to be able to improve thinking skills, and learning outcomes are directed to construct knowledge about mastery of new subject matter. In accordance with the creative thinking skills needed to face the era of competition in the 4.0 revolution period. and the demands of the 21 st century are high competitiveness.

Creative thinking ability is the ability to use the mind more broadly to find new challenges in real life. Nurlaeli 2015 [4] said creative thinking ability is a form of high-level ability, namely the ability to process thoughts to generate new ideas. . Furthermore, creative thinking according to Nurlaeli 2015 [5] is a mental activity to build new ideas or ideas smoothly and flexibly). has the characteristics of fluency, flexibility, originality and elaboration.

In this regard, Tan (2003) in Rusman 2012 [6] said problem-based learning is a learning approach that is relevant to the demands of the 21st century. Because Margetson (1997) in Rusman 2012,[7] said problem-based learning curriculum can help improve skills development lifelong learning in an open, reflective, critical, creative, and active mindset. The curriculum facilitates successful problem solving, communication, group work and better interpersonal skills. Definitively Ibrahim in Trianto, 2007 [8] said problem-based learning was developed to assist students in developing thinking skills, problem solving and intellectual skills. Further Ibrahim and Nur in Rusman, 2014 [9] said that problem-based learning is one of the learning approaches used to stimulate students' higher-order thinking in problem-oriented real-world situations, including learning how to learn. On the other hand, S Indriani 2008 [10] said mind mapping is a learning strategy that can develop left and right brain abilities by deductively describing ideas. (general to specific)

Meanwhile, Mulyasa 2003 [11] said that education not yetable to produce quality human resources. Thus Tan (2000) in Rusman 2011 [12] said that not all teachers understand the concept of learning correctly. The results of TIMSS (in Nurlaela 2015[13] concluded that the higher-order thinking ability of Indonesian students is still low. Empirically, the above phenomenon is supported by low student learning outcomes, especially in terms of intellectual abilities with creative thinking skills. They tend to be less ready to answer HOTS-based assessment sheets.

From this phenomenon, it is suspected that the ability of lecturers to organize, condition learning, and choose learning models that are in accordance with expectations is still not professional. So it is less promising for the development of students' creative thinking and future demands. Semiawan 2010 [14] said that one of the learning models that can be used and has the potential to teach creative thinking skills is problem-based learning (PBM) with constructivism theory. Then the model has pillars of creative thinking skills, namely the components of associating, asking, observing, and experimenting.

Starting from the description, the following problems arise; (1) how is the development of problem-based learning models in improving the creative thinking skills of PGSD students and (2) how is the feasibility of the models developed in improving the creative thinking abilities of PGSD students. While the objectives of this study were to: (1) develop a problembased learning model in improving the creative thinking skills of PGSD students and (2) find out the results of the feasibility validation test of the developed model. 


\section{Method}

This type of research is development research that uses the ADDIE (Analysis, Design, Development, Implementation, and Evaluation) model. The goal is to produce a product through various trials. The product of this research is a learning model that can improve students' creative thinking skills, namely the problem-based learning model (PBM).

This research was conducted at the Faculty of Education (FIP) Unimed. The population was students of Smt IV PGSD FIP, while the sample was taken by purposive sampling technique, namely class $H$ and class $G$, size $n=80.0$ people. The data collection tool is a questionnaire with five choices according to the Likert scale, the data analysis is descriptive percentage. Technical analysis with the formula:

$$
\text { Ps }=\frac{\sum n}{\text { skormak }} \times 100 \%
$$

The assessment criteria according to the 2009 Arikunto formulation[15] are as follows:

Table 1. Eligibility Assessment Criteria.

\begin{tabular}{cc}
\hline Percentage & Criteria \\
\hline $81 \%-100 \%$ & Very worth it \\
$61 \%-80 \%$ & Worthy \\
$41 \%-60 \%$ & Eligible for revision \\
$21 \%-40 \%$ & Pretty decent \\
$<21 \%$ & Very unworthy \\
\hline
\end{tabular}

\section{Results and Discussion}

According to the ADDIE (Analysis, Design, Development, Implementation, and Evaluation) model, stages of use are carried out according to the ADDIE component.

\subsection{Analysis (Analysis)}

At this stage, the main activity is to analyze the need for the development of new learning models/methods and analyze the feasibility and requirements of developing new learning models/methods. More information Analysisit relates to: student needs; student characteristics; lecture material that is still poorly understood by students;

\subsection{Design (Design)}

The design stage includes several development plans, namely:

(1) Development of learning models in classroom action research (CAR) learning by testing CPM; (2) Designing learning scenarios; (3) Selection of teaching materials according to CPM; (4) Initial planning of learning devices; which is based on the competence of the subject; and (5) Designing a learning evaluation tool. 


\subsection{Development (Development)}

After the design stage, the researcher developed a model by producing a problem-based learning model. The product developed is validated by competent experts, so that it can be determined whether a product is feasible or not to be applied according to the needs determined at the analysis stage.

The model validation test was carried out by a design expert, Prof.DR. Efendi Napitupulu, MPd, and material expert by Mrs. Prof, DR, Naeklan Simbolon, MPd. Revise the model based on input from the validator, implement it carried out in CAR learning.

Testing the validity of the model was carried out twice, to explain the testing process. This is evidenced by the results of data analysis from the validator test concerned. As forthe results of the model validation test from the validator concerned one by one as follows:

Design Expert Validation Test Results. The results of the design expert validation test obtained are as shown in the following table:

Table 2. First Design Expert Validation Test Results.

\begin{tabular}{lcccc}
\hline \multicolumn{1}{c}{ Aspect } & Question List & Sign & \% & Description \\
\hline Rational model & 6 & 26 & $90 \%$ & Very feasible \\
Theoretical support & 5 & 20 & $84 \%$ & Very feasible \\
Syntax & 7 & 28 & $80 \%$ & Eligible \\
Social System (Collaboration) & 6 & 22 & $77 \%$ & Eligible \\
$\begin{array}{l}\text { Duties and Roles } \\
\text { Ifluence: instructional \& }\end{array}$ & 6 & 26 & $87 \%$ & Very decent \\
$\begin{array}{l}\text { accompaniment } \\
\begin{array}{l}\text { Achievement score/score } \\
\text { revision }\end{array}\end{array}$ & 5 & 16 & $64 \%$ & Eligible \\
& & & & \\
\end{tabular}

Based on the results of the validation test by design experts, in the table above, it can be concluded that the results of the first phase of the validation test obtained a score of 138 out of a total score of 175 with a feasibility percentage obtained of $78 \%$. The percentage value of the model design feasibility test is included in the "Enough" criteria with minor improvements.

After making improvements according to suggestions and input from the validator. Then the second instrument validation test on the model design became 40 items. Further testing is carried out by the validator concerned. The results of data processing are presented in the following table. 
Table 3. Second Design Expert Validation Test Results.

\begin{tabular}{lcccc}
\hline \multicolumn{1}{c}{ Aspect } & Question List & Sign & \% & Description \\
\hline Rational model & 6 & 26 & $86 \%$ & Very valuable \\
Theoretical support & 5 & 21 & $84 \%$ & Very valuable \\
Syntax & 7 & 32 & $91 \%$ & Very valuable \\
Social System (Collaboration) & 6 & 25 & $83 \%$ & Very valuable \\
Duties and Roles & 6 & 28 & $93 \%$ & Very valuable \\
Ifluence: instructional & 5 & 23 & $92 \%$ & Very valuable \\
Accompaniment impact & 5 & 23 & $92 \%$ & Very valuable \\
Achievement score/score & $\mathbf{4 0}$ & $\mathbf{1 7 8}$ & $\mathbf{8 9 \%}$ & Very valid \\
\hline
\end{tabular}

Based on the results of the Design Expert validation test, the table above can be explained that the second validation test scored 178 out of a total score of 200 with the percentage of feasibility obtained was $89 \%$. The percentage value obtained in this second validation test is included in the "Very Eligible" criteria. Thus, based on the results of the model feasibility test by design experts, it was concluded that the developed model was feasible to be implemented in PGDG FIP Unimed student lectures in the PTK course.

To explain the results of this test by naked eye, it can be seen in the following bar chart:

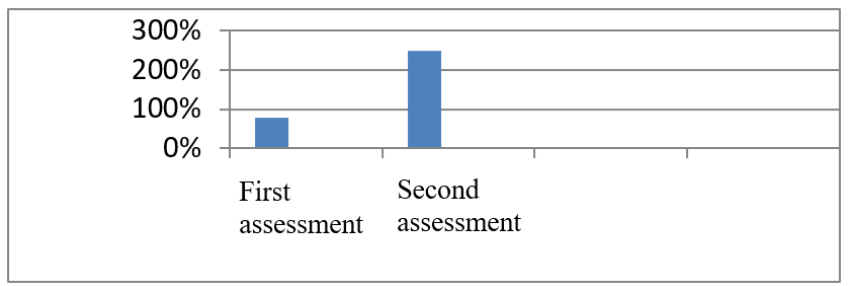

Fig.1. Design Validation Test Results Diagram.

Material Expert Validation Test Results. Material expert validation carried out aims to determine the feasibility of the material model developed in learning. Material expert validation was carried out twice to get the maximum feasibility of the model. The results of stage 1 validation filled in by model material experts are presented in the following table:

Table 4. Material Expert Validation Test I.

\begin{tabular}{lcccc}
\hline \multicolumn{1}{c}{ Aspect } & Question List & Sign & \% & Note \\
\hline $\begin{array}{l}\text { RPP compatibility } \\
\text { Lecture Achievement (BPS) } \\
\text { revision }\end{array}$ & 5 & 18 & $72 \%$ & $\begin{array}{c}\text { Very feasible } \\
\text { Coverage suitability }\end{array}$ \\
$\begin{array}{l}\text { material with model } \\
\text { Model selection // strategy }\end{array}$ & 7 & 15 & $60 \%$ & Eligible for revision \\
learning & 6 & 22 & $73 \%$ & Eligible \\
$\begin{array}{l}\text { Planning for college } \\
\text { activities valuable } \\
\text { Resources and equipment }\end{array}$ & 5 & 21 & $84 \%$ & Very valuable \\
\hline
\end{tabular}




\begin{tabular}{lcccc}
\hline supporting facilities & & & & \\
BPS assessment design & 6 & 21 & $70 \%$ & Eligible \\
$\begin{array}{l}\text { Score/achievement score } \\
\text { revision }\end{array}$ & $\mathbf{4 0}$ & $\mathbf{1 4 7}$ & $\mathbf{7 4 \%}$ & $\begin{array}{c}\text { Worth minor } \\
\text { revision }\end{array}$ \\
\hline
\end{tabular}

Based on the material feasibility validation test data in the table above. it can be explained that the results of the material feasibility assessment by the expert got a score of 147 out of a total score of 200 with a percentage of the feasibility of the material model being $74 \%$. Based on the score acquisition criteria which are converted into the percentage above, the material aspects to be used in the learning model are included in the Valid criteria. However, apart from the assessment, in the questionnaire there are also criticisms, suggestions and conclusions given at the end of the assessment of the learning model that aspects of the assessment indicators still need to be added indicators which include: (1) HOTS FormulationBased Lecture Achievement (BPS); (2) application of CPM assessment with HOTS

After processing the data from the second validation test instrument, the results are as in the following table:

Table 5. The Result of the Validity Test of the Questionnaire Material.

\begin{tabular}{lcccc}
\hline \multicolumn{1}{c}{ Aspect } & Question List & Sign & \% & Information \\
\hline $\begin{array}{l}\text { RPP compatibility } \\
\begin{array}{l}\text { Lecture Achievement (BPS) } \\
\text { revision }\end{array}\end{array}$ & 5 & 23 & $92 \%$ & Very feasible \\
$\begin{array}{l}\text { Coverage suitability } \\
\text { material with model }\end{array}$ & 7 & 23 & $92 \%$ & Very decent \\
$\begin{array}{l}\text { Model selection // strategy } \\
\text { learning }\end{array}$ & 6 & 33 & $94 \%$ & Very feasible \\
$\begin{array}{l}\text { Activity planning } \\
\text { BPS assessment design }\end{array}$ & 6 & $90 \%$ & Very feasible \\
Value/achievement score & 6 & 27 & $90 \%$ & Very feasible \\
& $\mathbf{4 0}$ & $\mathbf{1 8 4}$ & $\mathbf{9 2 \%}$ & $\begin{array}{l}\text { Very feasible } \\
\text { Very decent }\end{array}$ \\
\hline
\end{tabular}

Based on table 5. above, it can be concluded that the results of the second stage of thevalidation test obtained a score of 184 with a feasibility percentage of $92 \%$. The percentage value of the feasibility test The material above is included in the very feasible category without revision.

Thus, based on the results of the model feasibility test by material experts, it was concluded that the model developed was feasible in the lectures of PGDG FIP Unimed students in the PTK course.

To explain the results of this test with the naked eye, we can see in the following diagram:

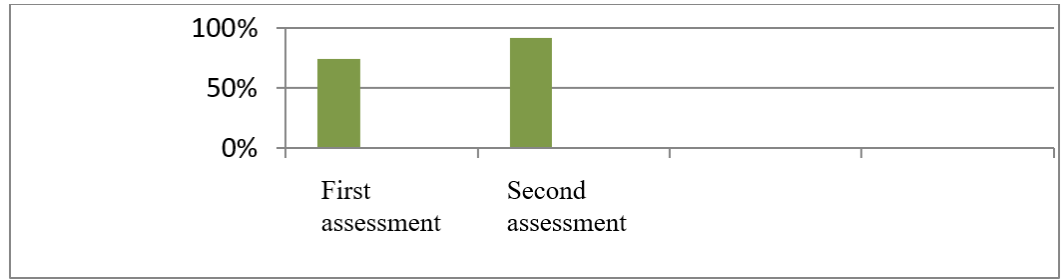

Fig. 2. Material validation test results diagram. 
The development of the problem-based learning model in improving the creative thinking skills of PGSD students is carried out using the ADDIE Model. From the stages of the model the researchers did:

a. Analysis relating to: student needs; student characteristics; lecture material that is still poorly understood by students;

b. Design from the results of the analysis, the researchers agreed to design a product that is able to answer the results of the analysis. The design steps to be followed are: first to create an RPS; secondly make the concept of problem-based learning model to be developed; thirdly designing materials to be integrated with the model; and fourth to create an MFI.

c. Development, after the design stage, the researcher develops a model by producing a problem-based learning model.

The product developed is validated by competent experts, so that it can be determined whether a product is feasible or not to be applied according to the needs determined at the analysis stage.

Based on the results of the validation tests carried out, it was concluded that the learning model developed was very feasible to be applied in CAR learning for PGSD FIP Unimed students. This is evidenced by the results of data analysis from the validation test as follows:

1. The results of the feasibility validation test by design experts in the first stage obtained a score of 138 out of a total score of 175 with the percentage of feasibility obtained at $78 \%$. After making improvements according to the validator's criticism suggestions. Then a second validation test was carried out, a score of 178 out of a total score of 200 and the percentage of eligibility obtained was $89 \%$.

2. The results of the feasibility validation test by material experts in the first stage obtained a score of 147 out of a total score of 200 with the percentage of feasibility obtained was $74 \%$. After making improvements according to the validator's criticism suggestions, namely (1) Lecture Results Formulation (BPS) based on HOTS; (2) application of CPM assessment with HOTS. Then a second validation test was carried out, a score of 184 out of a total score of 200 and the percentage of eligibility obtained was $92 \%$.

The test results are supported by theory. Connection. Akbar (2013) said: model validation is an effort to obtain a learning model with high validity and related to learning experts related to the material, objectives, and with theoretical support. Furthermore, Huda (2014: 72) said that each developed model is described in 5 structures, namely:

(1) Syntax (stages) (2); Social system, (3) Teacher's duties/roles: (4) Effect refers to the effect caused by each model, and (5) Effect of mentoring. . Finally, Akbar (2013) said: the instrument of validation of the learning model is based on the theory of model development oriented to constructivism theory, process standards.

\section{Conclusion}

From this research review, it was concluded that the results of the Phase II model feasibility validation test by design experts stated that the developed model was suitable for use in PGSD student lectures in the PTK course with a score of 178 and a percentage value of $89 \%$. II by the material expert stated that the model developed was suitable for use in PGSD student lectures in the PTK course with a score of 184 and a percentage value of $92 \%$. 
The consistency of the results of the validity test of the model means that learning which refers to the process of increasing students' creative thinking, starting from finding actual problems, solving them, the results must be communicated so that students are conditioned to do self-reflection; In this learning, one of the lecturers' activities to develop students' creative thinking is by asking open questions (divergent) and creating challenging situations and conditions, so that students have the opportunity to give more than one correct answer with a more flexible mindset. In addition, students' analytical, critical and creative thinking skills can be trained with the existing challenges. So that the mindset of students is more flexible or flexible as in the development of problem-based learning models.

\section{References}

[1] Akbar SD. Learning Instruments. Bandung: Rosdakarya; 2013.

[2] Danim S. New Vision of School Management: from Borocrat Unit to Academic Institution. Jakarta: Earth Literacy; 2000.

[3] Huda M. Teaching and Learning Model. Yogyakarta: Student Library; 2013.

[4] Nurlaela L, et al. Creative thinking learning strategies. Surabaya: Waves; 2015.

[5] Nurlaeli. Relationship between Parental Interaction with Skills. Jakarta: Syarid Hidayatullah State Islamic University; 2015.

[6] Sagala S. The Concept and Meaning of Learning. Bandung: Alfabeta; 2003.

[7] Setyosari P. Methods of Educational Research and Development. Jakarta: Earth of Letters; 2013.

[8] Slamet. Learning Factors and Their Influence. Jakarta: Rineka Cipta; 2015.

[9] Sugiyono. Quantitative, Qualitative and R\&D Research Methods. Bandung: Alfabeta; 2014. 